\title{
Arterial wall lesions after pulmonary embolism, especially ruptures and aneurysms
}

\author{
SIMON SEVITT \\ From the Pathology Department, Accident Hospital, Birmingham
}

SYNOPSIS During an histological study of pulmonary thromboembolism, arterial wall splits, many associated with saccular microaneurysms, were observed in association with emboli or their fibrous residue. Other aneurysmal lesions, non-inflammatory focal medial necrosis, and medial scars were also seen in a few cases. The nature of the arterial rents indicates that they arose by mechanical splitting after acute stretching of the artery. at the time of embolic impaction. Saccular aneurysms then developed in some. Impaction could also have caused the foci of medial necrosis while the medial scars could represent healed former necrosis or rupture. Though the observed incidence of lesions was relatively low, this seems to be due to their small sizes and the sampling inherent in conventional histological analysis. It is concluded that arterial splits are probably a common effect of pulmonary embolism and often give rise to small aneurysms.

Ruptures of arteries and small saccular aneurysms were observed during an histological analysis of organization and resolution of pulmonary thromboemboli; the study was then extended to include necrosis and scars in the tunica media. Though cases of false and dissecting aneurysm and arterial rupture after systemic and pulmonary embolism have been reported recently by Salyer et al (1974) the kinds of rupture and aneurysms described here do not seem to have been described hitherto. They are believed to be mechanical in origin following acute impact of emboli within the arteries.

\section{Material and methods}

The present report is based on an histological collection from 85 subjects at necropsy of pulmonary thromboemboli sectioned in situ. Details of the subjects are outlined in table I. Ages ranged from 12 to 94 years but most patients were elderly. More than half were females. Death followed trauma in most cases but some had been burned and a few died from natural diseases. The largest single group $(34 \%)$ were elderly patients with a fractured neck of femur (fractured hip). Survival time after injury ranged from three days to 12 months but nearly two-thirds of the patients died two weeks or more and $36 \%$ died one month or more after the accident.

Received for publication 13 January 1976

\begin{tabular}{lc}
\hline & No. of cases \\
\hline Sex: & \\
Male & 38 \\
Female & 47 \\
Age: & \\
$12-60$ yr & 12 \\
$61-80$ & 43 \\
$81-94$ & 30 \\
Main diagnosis: & 29 \\
Fractured hip & 6 \\
Other fractures of femur & 13 \\
Cerebral injury & 21 \\
Other trauma & 11 \\
Burns & 5 \\
Natural disease & 13 \\
Survival-time after accident ${ }^{1}:$ & 16 \\
< 1 wk & 25 \\
$1-2$ wk & 24 \\
$2-4$ wk & 7 \\
1-3 mth & 42 \\
Major pulmonary thromboembolism & \\
\hline
\end{tabular}

Table I Details of the 85 patients

'Or admission in five cases with natural disease

Full postmortem examinations were performed. Lung emboli had been searched for by opening with scissors the main arterial tree as previously reported (Sevitt and Gallagher, 1961). Gross details of emboli found were recorded on standard diagrams of the lung arteries, and many emboli were photographed in situ. Emboli in 42 subjects ( $49.4 \%$ ) were sufficiently large or numerous or both to be judged causal or 
contributory to death. Selected blocks of lung tissue containing emboli, pieces of free emboli, and blocks from infarcts were removed for histology. Portions from upper and lower lobes of both lungs were also removed for routine histology and some were found to contain emboli. Tissues were fixed in neutral formol-saline and processed to paraffin wax. Sections from all blocks were reviewed, and those from 165 blocks of lung tissue containing 203 emboli or their residue or both were selected for this study. Relevant blocks averaged almost two per case, ranging from one to five. Sections were stained by a battery of methods to differentiate nucleated cells, fibrin, platelets, haemosiderin, collagen, and elastic tissue, viz, aqueous toluidine blue, Lendrum's picroMallory, phosphotungstic acid-haematoxylin (PTAH), Perl's technique, van Gieson and Moore's elastic tissue (EVG) method, and haematoxylin and eosin. Serial sections were made only in special cases so that the frequency of arterial lesions found cer- $\overrightarrow{\vec{B}}$ tainly underestimates their true incidence.

\section{Results}

The arterial wall lesions were found in 16 of the 850

\begin{tabular}{|c|c|c|c|}
\hline Nature of lesion & No. of cases & $\begin{array}{l}\text { No. of } \\
\text { arteries } \\
\text { affected }\end{array}$ & No. of lesions \\
\hline $\begin{array}{l}\text { Unhealed arterial rupture } \\
\text { Saccular aneurysm } \\
\text { Other aneurysmal lesion } \\
\text { Focal medial scar } \\
\text { Focal medial necrosis or } \\
\text { degeneration }\end{array}$ & $\begin{array}{l}9 \\
7 \\
2 \\
3 \\
3\end{array}$ & $\begin{array}{r}12 \\
8 \\
2 \\
3 \\
3\end{array}$ & $\begin{array}{r}14 \\
8 \\
2 \\
3 \\
3\end{array}$ \\
\hline
\end{tabular}

Table II Pulmonary arterial lesions in 16 subjects

\begin{tabular}{|c|c|c|c|c|c|c|c|c|}
\hline \multirow{2}{*}{$\begin{array}{l}\text { Case } \\
\text { no. }\end{array}$} & \multirow{2}{*}{$\begin{array}{l}\text { Sex, } \\
\text { age }\end{array}$} & \multirow[t]{2}{*}{ Main diagnosis } & \multirow{2}{*}{$\begin{array}{l}\text { Survival } \\
\text { time }\end{array}$} & \multicolumn{5}{|c|}{ Artery and embolus } \\
\hline & & & & $\begin{array}{l}\text { Location } \\
\text { in lung }\end{array}$ & $\begin{array}{l}\text { Diameter } \\
\text { of artery }\end{array}$ & Rupture & Embolus & Aueurysm \\
\hline 1 & $\begin{array}{l}\mathbf{M} \\
\mathbf{3 2}\end{array}$ & $\begin{array}{l}\text { Chest injury, pulm. } \\
\text { embolism }\end{array}$ & $4 d$ & LLL & $10 \mathrm{~mm}$ & $\begin{array}{l}\text { (1) Narrow incomplete } \\
\text { split }\end{array}$ & Recent & 0 \\
\hline 2 & $\begin{array}{l}M \\
67\end{array}$ & $\begin{array}{l}\text { Multiple injuries, } \\
\text { pulm. embolism }\end{array}$ & $3 \mathrm{mth}$ & $\begin{array}{l}\text { RLL } \\
\text { RUL }\end{array}$ & $\begin{array}{l}2.0 \mathrm{~mm} \\
4.0 \mathrm{~mm} \\
3.0 \mathrm{~mm}\end{array}$ & $\begin{array}{l}\text { (2) Two large defects } \\
\text { Narrow split } \\
\text { Zonal ruptures } \\
\text { opposite sides } \\
\text { Zonal ruptures } \\
\text { opposite sides }\end{array}$ & $\begin{array}{l}\text { Recent } \\
\text { Organizing to split. } \\
\left\{\begin{array}{l}\text { Macrophages, } \\
\text { haemosiderin } \\
+++ \text { in } \\
\text { rupture zones }\end{array}\right.\end{array}$ & $\begin{array}{l}\mathbf{0} \\
\mathbf{0} \\
\mathbf{0}\end{array}$ \\
\hline 3 & $\begin{array}{l}\mathbf{M} \\
78\end{array}$ & $\begin{array}{l}\text { Cerebral and chest } \\
\text { injury, pulm. } \\
\text { embolism }\end{array}$ & $17 \mathrm{~d}$ & LLL & $0.25 \mathrm{~mm}$ & Narrow split & $\begin{array}{l}\text { No embolus in } \\
\text { affected vessel. } \\
\text { Organizing embolus } \\
\text { in nearby artery }\end{array}$ & Narrow microaneurysm \\
\hline 4 & $\begin{array}{l}M \\
62\end{array}$ & Cerebral injury & $12 \mathrm{~d}$ & $\begin{array}{r}\text { Infarct } \\
\text { LLL } \\
\text { Infarct } \\
\text { LLL }\end{array}$ & $\begin{array}{l}0.05 \mathrm{~mm} \\
0.5 \mathrm{~mm}\end{array}$ & $\begin{array}{l}\text { Narrow split } \\
\text { Narrow split }\end{array}$ & $\begin{array}{l}\text { Fibrous intimal } \\
\text { plaque } \\
\text { Recent }\end{array}$ & $\begin{array}{l}\text { Narrow micro- } \\
\text { aneurysm } \\
\text { Berry micro- } \\
\text { aneurysm } \\
0.05 \mathrm{~mm} \text { diam }\end{array}$ \\
\hline 5 & $\begin{array}{l}F \\
68\end{array}$ & $\begin{array}{l}\text { Brain abscess, } \\
\text { mastoiditis, } \\
\text { pulm. embolism }\end{array}$ & $14 d$ & $\begin{array}{l}\text { Major } \\
\text { artery } \\
\text { right } \\
\text { lung }\end{array}$ & $10 \mathrm{~mm}$ & Opened split & Early organization & Saccular, $1.2 \mathrm{~mm}$ diam \\
\hline 6 & $\begin{array}{l}M \\
42\end{array}$ & $\begin{array}{l}\text { Fractured tibia and } \\
\text { foot, } \\
\text { bronchopneumonia }\end{array}$ & $47 d$ & RLL & $2.0 \mathrm{~mm}$ & Opened split & $\begin{array}{l}\text { Occlusive fully } \\
\text { organized }\end{array}$ & Saccular, $0.4 \mathrm{~mm}$ diam \\
\hline 7 & $\begin{array}{l}\mathbf{M} \\
39\end{array}$ & Cerebral injury & $5 \mathrm{~d}$ & $\begin{array}{c}\text { Infarct } \\
\text { LLL }\end{array}$ & $1.0 \mathrm{~mm}$ & Opened split & $\begin{array}{l}\text { Focus early } \\
\text { organization }\end{array}$ & $\begin{array}{l}\text { Saccular, } 0.08 \mathrm{~mm} \\
\text { diam }\end{array}$ \\
\hline 8 & $\begin{array}{l}F \\
89\end{array}$ & $\begin{array}{l}\text { Hypertension, } \\
\text { fractured neck of } \\
\text { femur }\end{array}$ & $18 \mathrm{~d}$ & LLL & $2.5 \mathrm{~mm}$ & Opened split & $\begin{array}{r}\text { Fibrous network, } \\
\text { intimal fibrosis }\end{array}$ & $\begin{array}{l}\text { Saccular, } 0.3 \text { by } 1.0 \\
\mathrm{~mm}\end{array}$ \\
\hline 9 & $\begin{array}{l}F \\
78\end{array}$ & $\begin{array}{l}\text { Renal failure, } \\
\text { septicaemia, } \\
\text { fractured neck of } \\
\text { femur }\end{array}$ & $7 \mathrm{~d}$ & RLL & $4.0 \mathrm{~mm}$ & Opened split & Early organization & Saccular, $0.7 \mathrm{~mm}$ diam \\
\hline 10 & $\begin{array}{l}F \\
81\end{array}$ & $\begin{array}{l}\text { Fractured femur, } \\
\text { pulm. embolism }\end{array}$ & $3 \mathrm{mth}$ & Right lung & $\begin{array}{l}0.25 \mathrm{~mm} \\
\text { branch } \\
\text { of large } \\
\text { artery }\end{array}$ & Not seen & See text & $\begin{array}{l}\text { Aneurysmal dilatation } \\
\text { occluded by } \\
\text { organized thrombus }\end{array}$ \\
\hline 11 & $\begin{array}{l}\mathbf{F} \\
71\end{array}$ & $\begin{array}{l}\text { Fractured wrist, } \\
\text { pulm. embolism }\end{array}$ & $15 \mathrm{~d}$ & $\begin{array}{l}\text { Right lung } \\
\text { near } \\
\text { large } \\
\text { artery } \\
\text { with } \\
\text { embolus }\end{array}$ & $1.5 \mathrm{~mm}$ & Not seen & See text & $\begin{array}{l}\text { Possible dissecting } \\
\text { aneurysm }\end{array}$ \\
\hline
\end{tabular}

Table III Cases with pulmonary arterial rupture or aneurysms or both 


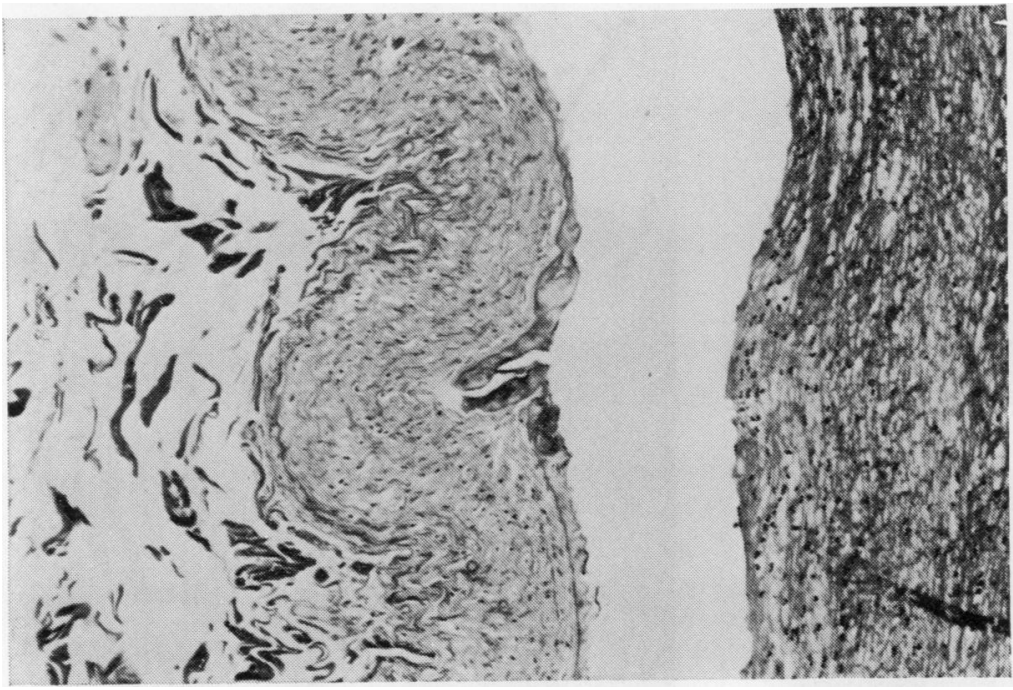

Fig 1 Case 1. Partial split of the media of a pulmonary artery lined by a coagulum. Embolus on the right. Picromallory (PM) $\times 112$

cases $(18 \cdot 8 \%)$. This excludes other changes secondary to emboli, such as acute inflammatory changes in the wall and adventitial haemorrhage, and also long-term products of or reactions to emboli, such as fibrous thickenings in the intima and arterial infiltration by foam cells. Thirty lesions were found, affecting 18 arteries in the 16 cases (table II). Unhealed arterial ruptures were observed in nine subjects, the 14 lesions affecting 12 vessels. In seven of these cases, saccular aneurysms were present at the rupture sites, eight arteries being affected. Other aneurysmal lesions were observed in two subjects, focal scars in the media in three patients, and foci of medial necrosis or degeneration in three others.

ARTERIAL RUPTURES AND ANEURYSMS

These were often linked since the saccular aneurysms were derived from splits in the arterial wall.

\section{Pulmonary arterial ruptures}

Details of the 14 lesions and the nine affected subjects are given in table III (cases 1 to 9). Well-defined narrow splits or fissures passed transversely and sharply into the media in four cases, five arteries being affected (figs 1,3 , and 4). The vessels ranged from a tiny one only $0.05 \mathrm{~mm}$ diameter to a large artery $10 \mathrm{~mm}$ diameter. In cases 1 and 2 the rents were not complicated by aneurysms. One split involved less than half the width of the thick musculoelastic media of a large artery (fig 1) and was lined by a narrow layer of coagulated protein also adhering to the intima nearby. The other rupture affected a $2 \mathrm{~mm}$ diameter vessel extending almost to the adventitia (fig 3). The intima around it had become thickened and anchored to the embolus by fibrosis, and flattened cells had spread over the surfaces of the rent.

Three other medial splits (case 3 and two in case 4) extended into the adventitia as narrow diverticula lined by thinned media (fig 4). They were saccular microaneurysms. The arteries affected were 0.25 , 0.05 , and $0.5 \mathrm{~mm}$ diameter respectively. One contained a recent embolus, and another (case 4) had a fibrous intimal plaque on the wall opposite the split. However, neither embolus nor fibrous residue was associated with the rupture in case 3 (fig 4) though an organizing embolus was present in an artery nearby. This suggests that the embolus responsible for the rupture had moved or disappeared.

In five cases (5 to 9) the splits had widened somewhat, forming the openings of well-defined berry aneurysms (vide infra).

Other ruptures were not narrow splits. The large artery in case 1 affected by a partial split (fig 1) also had two separated ruptures near one another in another part of the vessel, thereby exposing the thrombus to the adventitia over zones measuring 0.7 and $3.0 \mathrm{~mm}$ long respectively. Part of a separated rupture is shown in figure 2. Groups of polymorphs, some macrophages, and free haemorrhage had collected in the gaps between the thrombus and adventitia. The second and third ruptures in case 2 affected arteries different from the one showing the narrow split. Zonal areas of rupture on opposite sides of vessels $4 \mathrm{~mm}$ and $3 \mathrm{~mm}$ diameter respectively were largely obscured by cellular zones containing many 


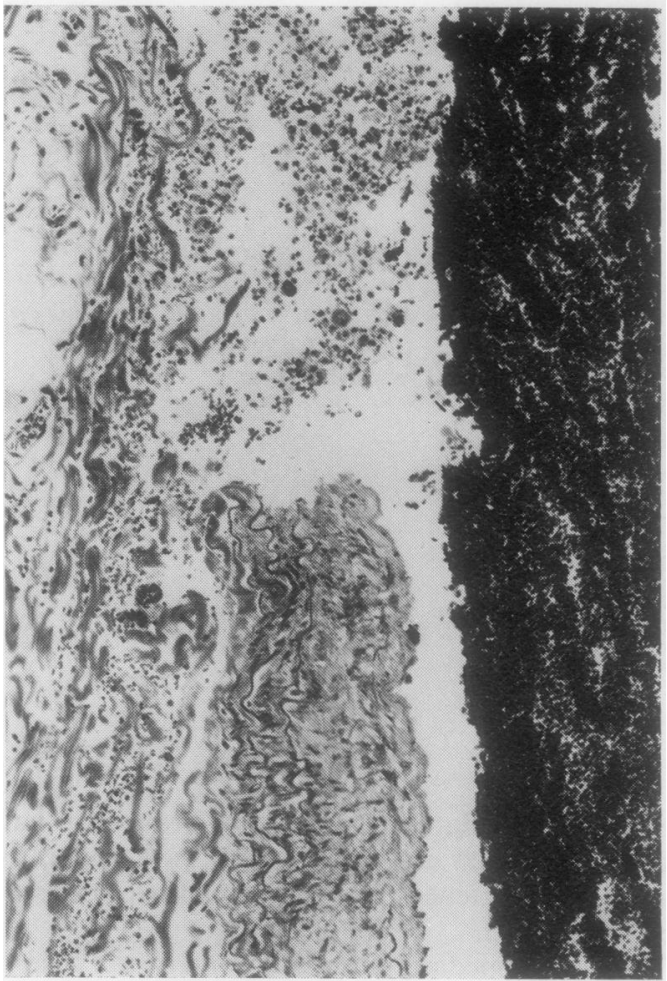

Fig 2 Case 1. Edge of the separated rupture affecting the same artery as in figure 1. Note infiltration of leucocytes between the thrombus (right) and the exposed adventitia. Phosphotungstic acid haematoxylin, $\times 105$

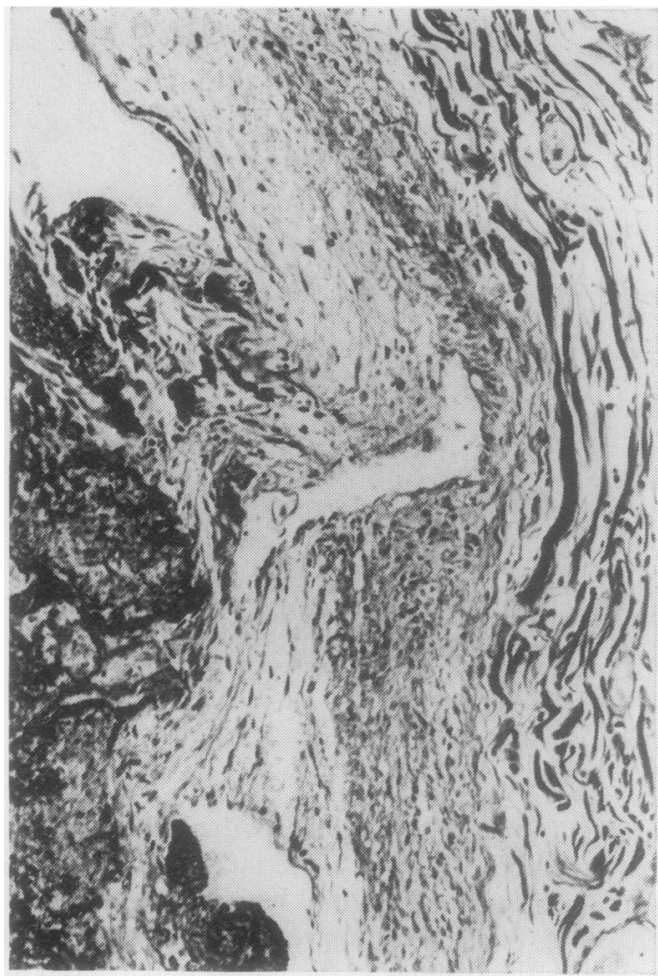

Fig 3 Case 2. Almost full-thickness split in the media of an artery. The rupture has become lined by flat cells and the intima around it is anchored to the embolus (left) by invading fibro-endothelial cells. PM $\times 105$

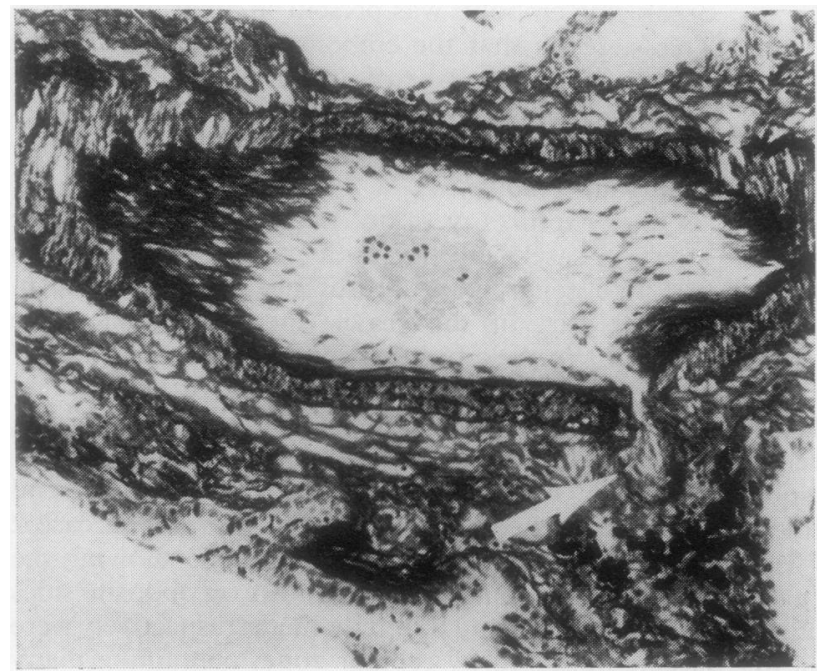

Fig 4 Case 3. Arrow points to a narrow rupture of a small artery which extends into van Gieson $(E V G) \times 120$ 


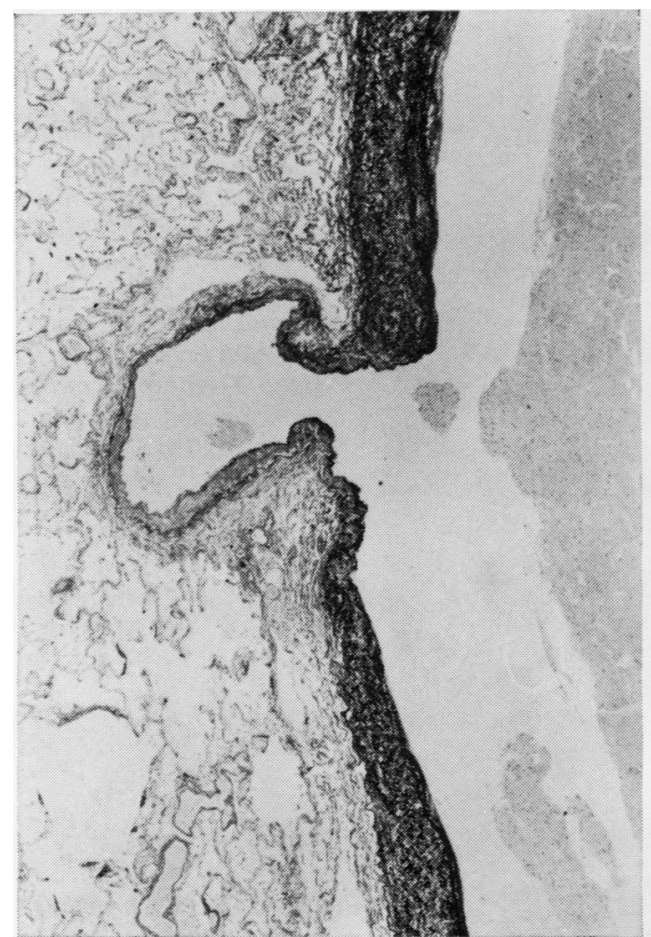

Fig 5

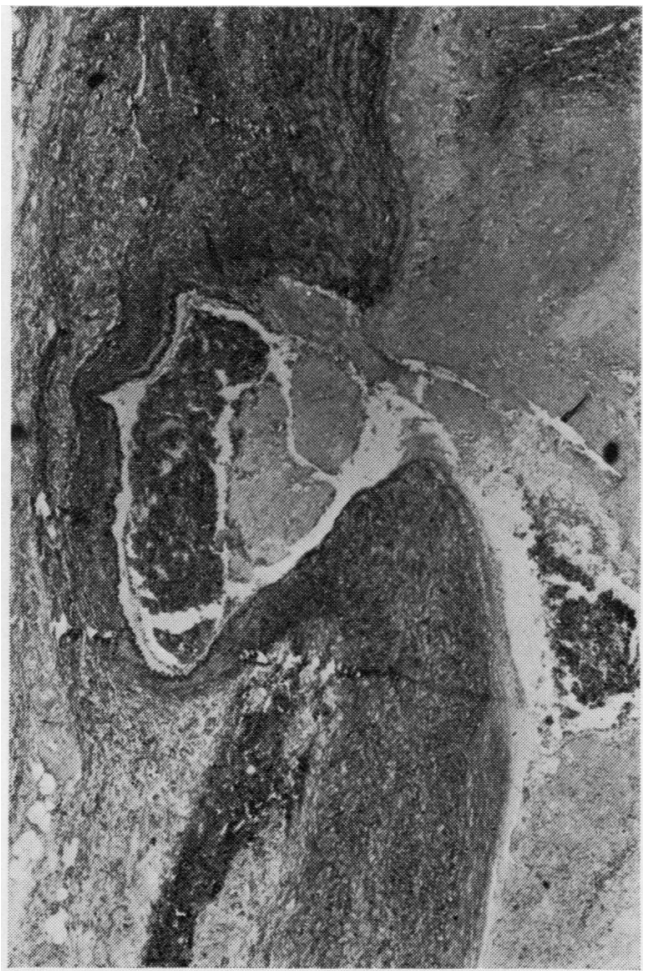

Fig 6

Fig 5 Case 9. Saccular microaneurysm at site of arterial rupture. Embolus on the right. EVG $\times 25$

Fig 6 Case 5. Small saccular aneurysm in a large artery following arterial rupture. Part of the thromboembolus (right) is in the sac. EVG $\times 25$

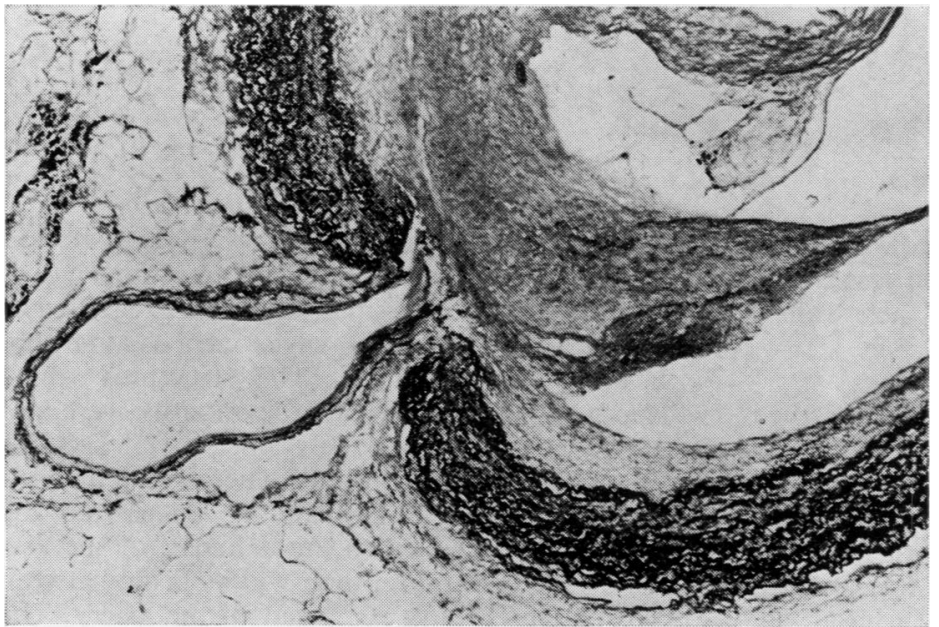

Fig 7 Case 8. Pear-shaped and thin-walled microaneurysm (left) bulging from an old arterial rupture. The former embolus is represented by fibroelastic bands and intimal thickening. EVG $\times \mathbf{4 0}$ 

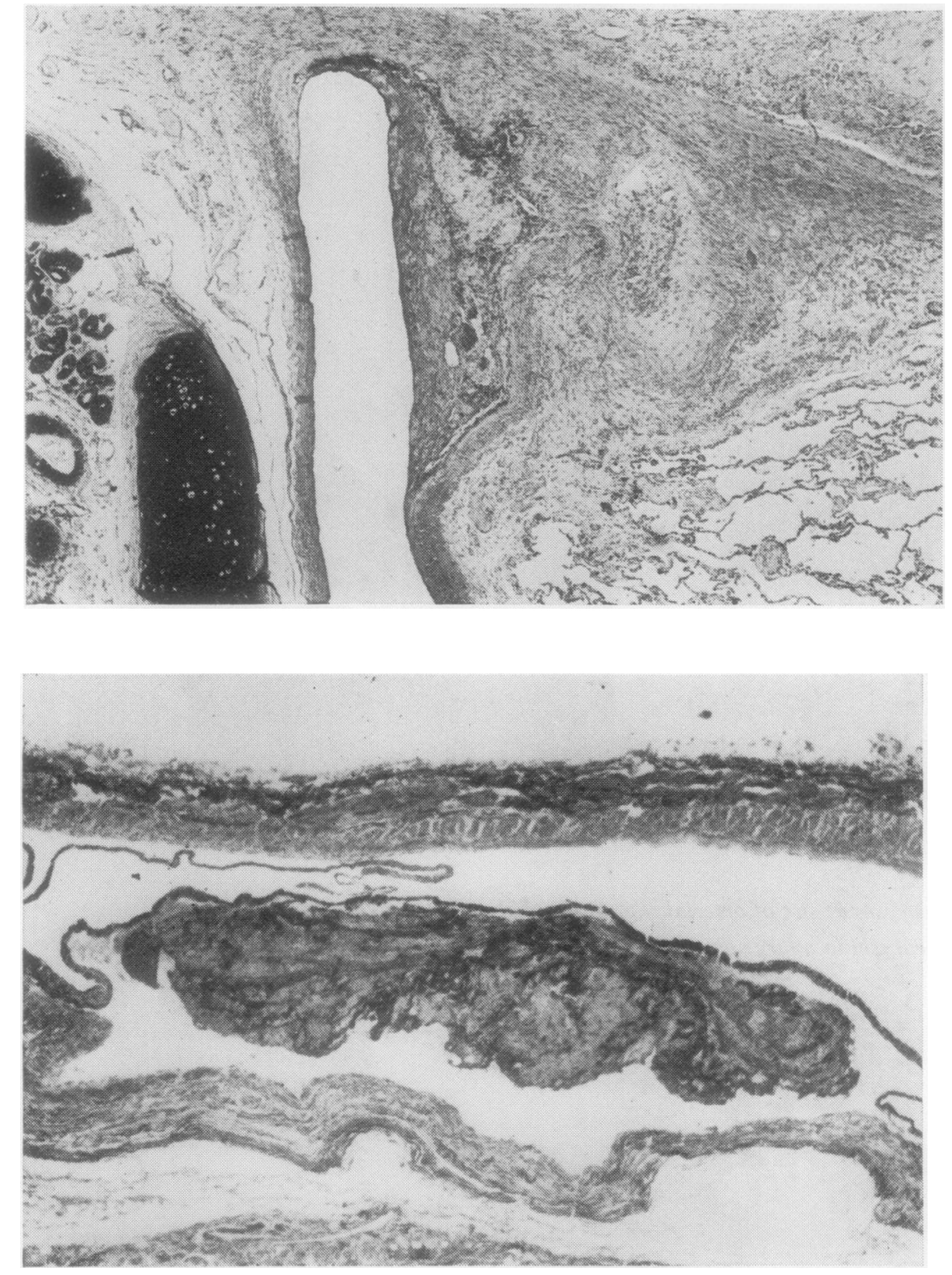

Fig 9 Case 11. Thrombus enclosed between two layers of the vessel wall. Possible dissecting aneurysm (see text). $P M \times 30$

haemosiderin-laden phagocytes. These extended locally into the thrombus and around the vessels and also heavily affected the intact parts of their walls.

\section{Saccular aneurysms}

Altogether eight saccular aneurysms were observed ( 7 cases) (table III). The three presenting as narrow diverticula from arterial splits have already been referred to. The other five (cases 5 to 9) presented as blind sacs, rounded, oval or roughly triangular in section, bulging from a part of the artery (figs 5 to 7). They were true aneurysms lined by a thin arterial wall containing a tunica media and internal elastica in $\stackrel{N}{N}$ continuity with those at the lips of the arterial gap at $\omega$ the mouth of the aneurysm. The gaps are regarded as split-ruptures which must have opened somewhat 0 with aneurysm formation. The structures which $\mathbb{D}$ widened in all planes from the mouths were not? branch arteries cut obliquely since serial sections showed that they were blind. The vessels affected ranged from 1.0 to $10 \mathrm{~mm}$ diameter. The sizes of the aneurysms were related to the diameter of the vessel at the site of rupture, their widths being between approximately 10 and $20 \%$ that of the artery. The 


\begin{tabular}{|c|c|c|c|c|c|c|c|}
\hline \multirow[t]{2}{*}{ Case no. } & \multirow[t]{2}{*}{ Sex, age } & \multirow[t]{2}{*}{ Main diagnosis } & \multirow[t]{2}{*}{ Survival time } & \multicolumn{4}{|l|}{ Affectedartery } \\
\hline & & & & Location in lung & Diam. of artery & Lesion & Embolus \\
\hline 12 & F 70 & $\begin{array}{l}\text { Fractured hip, myocardial } \\
\text { infarct, pulm. embolism }\end{array}$ & $3 \frac{1}{2} \mathrm{mth}$ & RLL & $0.25 \mathrm{~mm}$ & $\begin{array}{l}\text { Focal replacement of } \\
\text { media and internal } \\
\text { elastica lamina by } \\
\text { collagen }\end{array}$ & Organizing \\
\hline 13 & F 80 & $\begin{array}{l}\text { Fractured humerus, pulm. } \\
\text { embolism }\end{array}$ & 3 wk & Infarct RLL & $1 \mathrm{~mm}$ & $\begin{array}{l}\text { Focal replacement of } \\
\text { media by collagen }\end{array}$ & $\begin{array}{l}\text { Fully } \\
\text { organi- } \\
\text { zed }\end{array}$ \\
\hline 14 & F 94 & $\begin{array}{l}\text { Fractured humerus, pulm. } \\
\text { embolism }\end{array}$ & $3 \frac{1}{2} \mathrm{wk}$ & RLL & $1 \mathrm{~mm}$ & $\begin{array}{l}\text { Smallobliquescar of } \\
\text { media }\end{array}$ & $\begin{array}{c}\text { Eccentric } \\
\text { fibrous } \\
\text { plaque } \\
\text { of } \\
\text { intima }\end{array}$ \\
\hline
\end{tabular}

Table IV Cases with focal medial scars

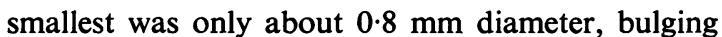
from a vessel only $1.0 \mathrm{~mm}$ diameter, and the largest was $1.2 \mathrm{~mm}$ diameter bulging from a large artery 10 mm diameter (fig 6). These two sacs contained part of a thrombus, but the others (figs 5 and 7) seemed empty though no doubt filled with fluid. Four of the affected arteries contained thromboemboli in various stages of organization. One was occluded by a fully organized thrombus (case 6) and another contained only fibrous remnants (case 8, fig 7). This artery, which was $4 \mathrm{~mm}$ diameter, had a pear-shaped aneurysm measuring $1.0 \mathrm{~mm}$ long by $0.3 \mathrm{~mm}$ bulging outwards at one point. The vessel showed considerable fibrous intimal thickening and several fibrous bands crossing the lumen. These were the organized products of an embolus, presumably the one which had ruptured the artery and produced the microaneurysm.

\section{Other aneurysms}

Two other lesions were seen. One was a local aneurysmal dilatation (fig 8) (table III, case 10). This was thrombosed. Its wide mouth bulged from one side of an artery, $0.25 \mathrm{~mm}$ diameter, near its origin from a large parent vessel. The parent artery contained an organizing mural embolus, part of which narrowed the origin of the affected branch proximal to the dilatation. This is seen in fig 11 in a section at another level where a focus of arterial necrosis is also evident nearby (vide infra). The dilatation was relatively shallow except for two or three smaller deep diverticula. The complex was occluded by a

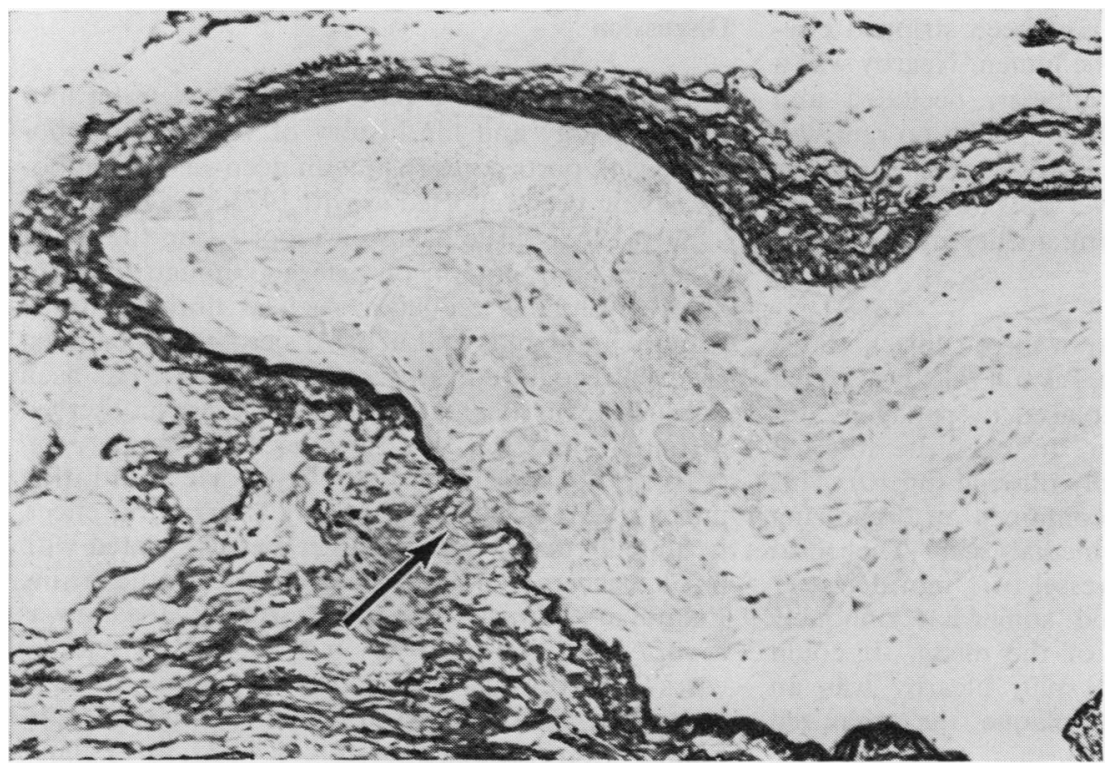

Fig 10 Case 12. Small lung artery showing $a$ focus of mural scarring and deficiency with loss of elastica (arrow). The embolus adheres to the mural scar and is in process of organic fragmentation. EVG $\times 120$ 


\begin{tabular}{|c|c|c|c|c|c|c|c|}
\hline \multirow[t]{2}{*}{ Case no. } & \multirow[t]{2}{*}{ Sex, age } & \multirow[t]{2}{*}{ Main diagnosis } & \multirow[t]{2}{*}{ Survival time } & \multicolumn{4}{|l|}{ Affected artery } \\
\hline & & & & Location in lung & Diameter & Lesion & Embolus \\
\hline $\begin{array}{l}10 \\
\text { (see table III) }\end{array}$ & F 81 & $\begin{array}{l}\text { Fractured femur, pulm. } \\
\text { embolism }\end{array}$ & $3 \mathrm{mth}$ & $\begin{array}{l}\text { Lobar artery } \\
\text { right lung }\end{array}$ & Large & $\begin{array}{l}\text { Focus of medial } \\
\text { necrosis opposite } \\
\text { embolus. Muscle } \\
\text { pyknotic. Elastica } \\
\text { lost }\end{array}$ & $\begin{array}{l}\text { Mural } \\
\text { organi- } \\
\text { zing }\end{array}$ \\
\hline 15 & F 92 & $\begin{array}{l}\text { Fractured hip, } \\
\text { bronchopneumonia }\end{array}$ & $25 \mathrm{~d}$ & RUL & $2 \mathrm{~mm}$ & $\begin{array}{l}\text { Focal strip of necrosis } \\
\text { of intima and } \\
\text { superficial media }\end{array}$ & Recent \\
\hline 16 & F 91 & $\begin{array}{l}20 \% \text { burns, pulm. } \\
\text { embolism }\end{array}$ & $1 \frac{1}{2} \mathrm{mth}$ & LLL & Bifurcation & $\begin{array}{l}\text { Degeneration of } \\
\text { smooth } \\
\text { muscle in media at } \\
\text { bifurcation }\end{array}$ & $\begin{array}{l}\text { Mural } \\
\text { organi- } \\
\text { zing } \\
\text { saddle } \\
\text { throm- } \\
\text { bus }\end{array}$ \\
\hline
\end{tabular}

Table V Cases with foci of medial necrosis or degeneration

highly organized thrombus containing fibrin remnants and haemosiderin with a flat surface flush with the lumen. It was bordered by a wall continuous with that of the artery from which it was derived, and also merging with the wall of the parent artery. The aneurysmal dilatation seems related to local embolism, and though arterial rupture was not seen, a healed split may have been obscured by the extensive fibrous anchoring of the occluding thrombus.

The other lesion (table III, case 11) presented as a thrombus enclosed between tunica media and a thin fibroelastic membrane continuous with the intima (fig 9). The vessel was relatively thin-walled and about $0.1 \mathrm{~mm}$ diameter. Whether it was an artery, a vein or even a large lymphatic channel is not certain, since various small lung vessels are thin-walled. The enclosing membrane was derived from intima and adjacent media which had also been stripped elsewhere, parts lying loose in the lumen. Nearby was a muscular artery, $5 \mathrm{~mm}$ diameter, occluded and distended by a recent embolus. Though no rent was seen, embolic rupture of this vessel into the other may have occurred at a level outside the plane of section, producing a dissecting aneurysm.

\section{Scars of the media}

Focal medial scars were seen in three subjects (table IV). In two (cases 12 and 13), the full thickness of the media was defective and replaced by collagen continuous with the adventitia. In one, the internal elastic lamina was also locally missing (fig 10). This artery, $0.25 \mathrm{~mm}$ diameter, contained an organizing embolus adhering to the medial scar. The third medial scar (case 14) in a vessel of $1 \mathrm{~mm}$ diameter was localized and extended somewhat obliquely through the full thickness of the media. It could represent a healed arterial split. Nearby was an eccentric fibroelastic intimal plaque, the organized product of an old embolus.

\section{Focal necrosis and degeneration}

Three examples of severe focal degeneration or necrosis of the media without infiltration by inflam-c matory or other cells were observed (table V). One क affected part of the wall of the parent artery near the opening of the branch with the aneurysmal dilatation (fig 11, case 10). The lesion was a shrunken pyknotic zone involving the thickness of the media, facing but separated from a mural organizing embolus. Another (case 15) involved a strip of intima and underlying media of a $2 \mathrm{~mm}$ diameter artery containing a recent embolus. The third (case 16) affected the bifurcation of an artery deep to an organizing saddle embolus. The intima was necrotic, the media locally swollen, $\exists$ and its smooth muscle ill defined and apparently disappearing.

\section{Discussion}

This study began as a part of an investigation into the pathology and life history of venous thromboembolism, parts concerned with deep vein thrombosis having been reported (Sevitt 1973a, b; 1974a, b).

Surprisingly little has been reported on the direct effects of lung emboli on arteries, though the products of embolic reduction such as fibrous intimal $N$ plaques and bands and networks crossing the lumen $N$ are well recognized; atheromatous residue has been $N$ produced experimentally and has also been observed ${ }^{\omega}$ in human material (for references see Hume et al (1970)). Focal arteritis with leucocyte infiltration $\stackrel{\circ}{\triangle}$ under recent emboli, presumably an irritative effect, $\stackrel{\mathcal{D}}{\rightarrow}$ is quite frequent and is sometimes associated with ${ }_{7}^{+}$ focal degenerate or necrotizing changes in the media. Pulmonary arterial necrosis, usually focal, was $\overrightarrow{\mathbb{D}}$ reported by Meyer (1960) in 11 out of 23 selected $\frac{\rho}{\odot}$ cases of recent occlusive thromboemboli, usually $\varrho$ associated with infiltration by inflammatory cells. Similar necroses have been described in systemic 8 


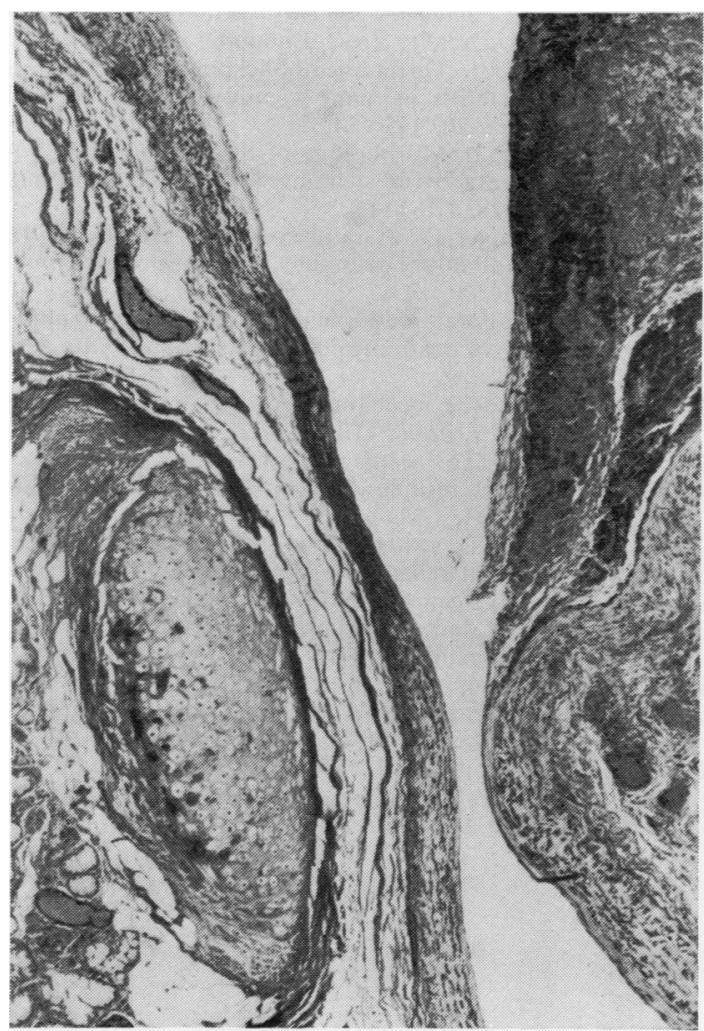

Fig 11 Case 10. Focus of medial necrosis (left) opposite a mural organizing embolus and just above the opening of a branch artery. The latter contained the aneurysmal dilatation shown in figure 8. PM $\times 44$

vessels by Haimovici (1950) and in both pulmonary and systemic arteries by Salyer, et al (1974) after embolism. Three examples of acute focal necrosis or severe degeneration of the media were found in the present series (3.5\% of cases), but these were non-inflammatory lesions. Mechanical trauma from local embolic impact seems the most likely of the possible mechanisms. Focal hypoxia from interference with diffusion from the lumen would not readily account for the necrotic focus opposite a mural embolus (fig 11), and local chemical action from a product of the thrombus seems unlikely to explain non-inflammatory lesions.

Three focal medial scars were seen ( $3.5 \%$ of cases). The two involving arterial wall segments under organizing or organized emboli (fig 10) could feasibly represent healed foci of either necrosis or rupture; but the third was small and localized and consistent with the healing of a small arterial rent. It may have been caused by the embolus which subsequently became reduced to the fibroelastic intimal pad seen near the medial scar.

Most of the lesions were arterial ruptures with or without the formation of local saccular microaneurysms. False and dissecting aneurysms with arterial rupture were reported by Salyer et al (1974), mostly in association with mesenteric, pancreatic or other systemic emboli, and they attributed these to ischaemic arterial damage caused by the thrombus in situ. They also observed one false aneurysm and one rupture in embolized lung vessels. Fusiform arteriolar aneurysms and cylindrical aneurysms of small arteries associated with hyaline thrombi were demonstrated by Orbison(1952) in the myocardium in a case of thrombotic thrombocytopenic purpura and he attributed these to pre-existing vascular defects. Neither explanation would account for the slit-like arterial rents now described, nor for the separated ruptures also observed in one artery with a slitrupture. These must have been mechanical. They were probably caused by acute stretching of the arterial wall by the embolus at the time of its impaction. Vessel dilatation from embolic impaction with stretching and thinning of much of the arterial wall is commonly seen around recent lung emboli. Adventitial haemorrhage is frequent also, and both point to vascular damage from impaction. Intima and media are susceptible to mechanical splitting by stretching, and this mechanism probably underlies most traumatic ruptures of the aorta (Sevitt, 1968) and other arteries. Narrow splits into or across the media were seen in five arteries $(2.5 \%)$ of four subjects $(4.7 \%)$, and saccular microaneurysms in eight arteries $(3.9 \%)$ of seven cases $(8.2 \%)$. Some of the latter presented as narrow diverticula clearly related to split-ruptures, but other aneurysms were dilated into sacs and the splits had opened somewhat to form the mouths of the aneurysms. Taking splitruptures and saccular aneurysms together, 10 arteries $(4.9 \%)$ in nine subjects $(10.6 \%)$ were seen to be affected; and taking all ruptures and aneurysms together, 14 arteries $(6.9 \%)$ in 11 subjects $(13 \%)$ were found to be involved. The true frequency is likely to be greater. Serial sections were not made routinely and hence other tiny ruptures and microaneurysms could have been present in other parts of the blocks. Moreover, the blocks contained only portions of emboli and only a proportion of the emboli were examined histologically. Further, it is likely that some emboli move distally after initial impact, and then ruptures may be present without emboli in the affected part, as was found in case 3 (fig 4). The conclusion seems warranted that arterial splits are a common feature of pulmonary embolism and often give rise to microaneurysms. Foci of medial necrosis and scarring are also likely to be much more frequent than was found. 
Can these ruptures and aneurysms produce clinical effects? Presumably not in most cases, but Thompson and Gerstl (1946) described a fatal globe-like aneurysm, about $12 \mathrm{~cm}$ diameter, in the right pulmonary artery of a 27 -year-old man associated with organizing bilateral thrombi in hilar and other major arteries. Their description of the large false aneurysm is consistent with its development from a true saccular aneurysm after arterial wall rupture by embolic impaction. The ability of thromboemboli to rupture arteries and cause aneurysms would not be confined to the lung. False and dissecting aneurysms have been demonstrated in embolized splenic, pancreatic, and mesenteric vessels (Salyer et al, 1974), and the possibility that some systemic saccular aneurysms, such as some of those in the circle of Willis, are produced by embolic rupture seems worthy of study.

\section{References}

Haimovici, H. (1950). Peripheral arterial embolism: a study of 330 unselected cases of embolism of the extremities. Angiology, 1, 20-45.

Hume, M., Sevitt, S., and Thomas, D. P. (1970). Venous
Thrombosis and Pulmonary Embolism. Harvard University 음 Press, Oxford University Press, London.

Meyer, J. S. (1960). Thromboembolic pulmonary arterial necrosis and arteritis in man. A study of 11 autopsied cases. Arch. Path. 70, 445-454.

Orbison, J. L. (1952). Morphology of thrombotic thrombocytopenic purpura with demonstration of aneurysms Amer. J. Path., 28, 129-144.

Salyer, W. R., Salyer D. C., and Hutchins, G. M. (1974). Local arterial wall injury caused by thromboemboli. Amer. J. Path., 75, 285-300.

Sevitt, S. (1968). Fatal road accidents. Injuries, complications and causes of death in 250 subjects. Brit. J. Surg., 55, $\overrightarrow{\vec{\omega}}$ 481-505./

Sevitt, S. (1973a). The mechanisms of canalisation in deep vein thrombosis. J. Path., 110, 153-165.

Sevitt, S. (1973b). The vascularization of deep-vein thrombi and their fibrous residue: a post-mortem angiographic study. J. Path., 111, 1-11.

Sevitt, S. (1974a). The structure and growth of valve pocket thrombi in femoral veins. J. clin. Path., 27, 517-528.

Sevitt, S. (1974b). Organisation of valve pocket thrombi and $ᄋ$ the anomalies of double thrombi and valve cusp involvement. Brit. J. Surg., 61, 641-649.

Sevitt, S. and Gallagher, N. G. (1961). Venous thrombosis and pulmonary embolism. A clinicopathological study in injured and burned patients. Brit. J. Surg., 48, 475-489.

Thompson, L. E. and Gerstl, B. (1946). Thrombo-angiitis of pulmonary vessels associated with aneurysm of pulmonary 6 artery. Report of a case. Arch. intern. Med., 77, 614-622. 